\title{
MAPKAPK5 wt Allele
}

National Cancer Institute

\section{Source}

National Cancer Institute. MAPKAPK5 wt Allele. NCI Thesaurus. Code C113082.

Human MAPKAPK5 wild-type allele is located in the vicinity of $12 q 24.13$ and is approximately $55 \mathrm{~kb}$ in length. This allele, which encodes MAP kinase-activated protein kinase 5 protein, plays a role in both the inhibition of mT ORC1 signaling and serine/threonine phosphorylation. 